\title{
DETERMINATION OF HETEROSIS IN EGGPLANT (Solanum melongena L.) HYBRIDS Badr, L.A. ${ }^{1}$; M.M. El-Nagar ${ }^{1}$; E. A. Hassan ${ }^{2}$;
}

\author{
Abeer A. El. Soliman ${ }^{3}$ and M. S. Amer ${ }^{3}$
}

(1) horticulture Dept., Fac. Agric., Benha unvi., (2) Plant Protection Dept., Benha unvi. and (3) Vegetables Breeding Dept., Hort. Res. Inst., Agricultural Research Center (ARC), Giza, Egypt.

\section{ABSTRACT}

Six parental genotypes i.e. Local cultivar white long $\left(\mathrm{P}_{1}\right)$, Local cultivar dark long $\left(\mathrm{P}_{2}\right)$ and Black beauty $\left(\mathrm{P}_{3}\right)$ (local cultivars of eggplant were obtained from Horticultural Research Institute, Agricultural Research center, Egypt, and three PIs viz., PI 408974 (P 4$)$, PI 470273 $\left(\mathrm{P}_{5}\right)$ and PI $542612\left(\mathrm{P}_{6}\right)$ (USDA gene bank, USA) and their fifteen $\mathrm{F}_{1}$ hybrids in a diallel cross system without reciprocals were used to estimate heterosis percentage relative to both mid ,better parents and two check hybrids for some characters in eggplant (Solanum melongena L.). The experiment was conducted at Kaha Research Farm, Kaliobia Governorate during three successive seasons of 2015 and 2018. The 23 genotypes ( 6 parents, $15 \mathrm{~F}_{1}$ hybrids and 2 check hybrids) were evaluated for yield and yield components to determine the heterosis effects .Hybrid vigour was documented for total yield, as well as, most fruit characters. In some crosses, high rate of parent heterosis were attained for these traits supporting the over dominance hypothesis. The cross $\left(\mathrm{P}_{3} \times \mathrm{P}_{6}\right)$ had the highest mid- parent and better parent heterosis value with $(230.02 \%$ and $218.85 \%$, respectively) for the total yield.

\section{INTRODUCTION}

Eggplant (Solanum melongena L.) is the fourth most important crop of the Solanaceae, which is widespread due to its high nutrition value and the taste of the fruits. Eggplant widely cultivated as one of the most important vegetables in both subtropical and tropical areas through the worldwide, it can play a vital role in achieving the nutritional security (Sarker et al., 2006). It is one of the most economic vegetable crops grown in Egypt. The total cultivated area in Egypt reached 106998 feddans in 2018/2019 producing 1346712 tons with an average of 12.586 tons/feddan ${ }^{\mathrm{Z}}$.

\footnotetext{
${ }^{\mathrm{z}}$ Department of Agricultural Statistics, Ministry of Agriculture and Land Reclamation, Egypt, 2017.
} 
Eggplant is an inexpensive food, thus a major food component of human diet in most developing home in the world over. So, its fruits are rich source of minerals like calcium, magnesium, potassium, iron, zinc and copper. It is also a fair source of fatty acids and it is used for medicinal purposes incurring diabetes, asthma, cholera, bronchitis and diarrhea. It is reported to stimulate the metabolism reduction of blood cholesterol. Leaf and fruit, fresh or dry produce marked drop in blood cholesterol level (Agoreyo et al., 2012; Nyadanu and Lowor, 2015).

Exploitation of hybrid vigour has become a potential tool for improvement in eggplant. Nagai and Kada (1926) were the first to observe hybrid vigour in eggplant. The commercial exploitation of this phenomenon has been possible in the eggplant, especially with increasing popularity of $F_{1}$ hybrids in eggplant, it is imperative to obtain such hybrids, having excellent quality coupled with high yields. In crop manifestation of heterotic effect for different economically important characters have been reported by many scientists (Joshi and Thakur, 2003; Thakur et al 2004; Ajjappalavar, 2006; Sao and Mehta 2010; Kumar et al., 2012 and Makani et al., 2013).

The development of an effective heterosis breeding programme in eggplant needs to elucidate the genetic nature and magnitude of quantitatively inherited traits and judge the potentiality of parents in hybrid combinations. Selection of parents for hybridization has to be based on the complete genetic information and prepotency of the potential parents. Identification and selection of flexible parental lines are required to be used in any hybridization programme to produce genetically modified and potentially rewarding germplasm by assembling fixable gene effects more or less in a homozygous line (Kumar et al., 2013, Pedapatiet et al., 2013, Potla et al., 2013, and Singh et al., 2013). With these points in view, heterosis and combining ability studies are prerequisite in any plant breeding programme, which provides the desired information regarding the varietals improvement or exploiting heterosis for commercial purposes (Singh et al., 2013).

\section{MATERIALS AND METHODS}

This study was carried out in 2015 to 2018 at Kaha Research Farm, Kaliobia Governorate to improve some economic characteristics in eggplant. Six genotypes of eggplant viz., Local cultivar white long $\left(\mathrm{P}_{1}\right)$, Local cultivar dark long $\left(\mathrm{P}_{2}\right)$ and Black beauty $\left(\mathrm{P}_{3}\right)$ (local cultivars of eggplant were obtained from Horticultural Research Institute, Agricultural Research center, Egypt, which were Local cultivar white 
long) and three PIs viz., PI $408974\left(\mathrm{P}_{4}\right)$, PI $470273\left(\mathrm{P}_{5}\right)$ and PI 542612 $\left(\mathrm{P}_{6}\right)$ (USDA gene bank, USA.) were selfed for one generation to keep its homozygosity and homogeneity. Parents were crossed to produce the $F_{1}$ hybrid seed in Diallel cross design, without reciprocals during 2016 and 2017early summer seasons. Seeds of these genotypes were sown on 15 Jan. in both years in foam seedling trays under unheated greenhouse conditions. Seedlings were transplanted on 15 Mar. in both years under unheated greenhouse conditions. The seeds of twenty three genotypes (six parents, fifteen $\mathrm{F}_{1}$ hybrids and two controls viz., La'ala (local hybrid, long white fruits) and Black King (imported commercial hybrid spreading in Egypt, round black fruits) were sown on 15 Feb. 2018 in foam seedling trays under unheated greenhouse conditions. Seedlings were transplanted on 15 Apr. 2018 summer season in the open field. A randomized complete block design (RCBD) with 3 replicates was used. Each replicate consisted of twenty-three experimental units (six parents, fifteen hybrids and two controls). Each experimental unit (EU) consisted of one row, $0.75 \mathrm{~m}$-wide and $5 \mathrm{~m}$-long for each row $\left(\mathrm{EU}\right.$ area $\left.=3.75 \mathrm{~m}^{2}\right)$. Plants were set $50 \mathrm{~cm}$ apart along the row and were given common agricultural practices. So, each EU consisted of ten plants. Five randomly selected plants were chosen in each EU to record the observations and the average from these five plants was worked out for statistical analysis. The studied characters were Plant height $(\mathrm{cm})$, number of branches per plant, number of days from planting date to first flower anthesis, Fruit length $(\mathrm{cm})$, Fruit diameter $(\mathrm{cm})$, average fruit weight $(\mathrm{g})$ and total furit per plant

\section{Statistical analysis}

Data obtained on genetic stability and evaluation of the $F_{1}$ hybrids experiments were statistically analyzed according to Gomez and Gomez (1984) and mean comparisons were based on the LSD test (Waller and Duncan, 1969).

Average degree of heterosis (ADH\%) was estimated as the increase or decrease percent of $\mathrm{F}_{1}$ performance over the mid-parent (MP) and better parent (BP) (Sinha and Khanna, 1975) as follows:-

$$
\begin{aligned}
& \text { Based on MP }=\left(\overline{F_{1}}-\overline{\mathrm{MP}} / \overline{\mathrm{MP}}\right) \times 100 \\
& \text { Based on } \mathrm{BP}=\left(\overline{\mathrm{F}_{1}}-\overline{\mathrm{BP}} / \overline{\mathbf{B P}}\right) \times 100
\end{aligned}
$$

Based on standard heterosis $=\left(F_{1}-\right.$ standard heterosis $/$ standard heterosis) $x 100$ 
Where $F_{1}$ was the mean performance of the $F_{1}$ hybrid, MP was the mean performance of $\mathrm{P}_{1}$ and $\mathrm{P}_{2}$ and $\mathrm{BP}$ was the mean performance of the better parent.

\section{RESULTS AND DISCUSSION \\ Mean performance}

Mean performance of the tested six eggplant parental genotypes, their $15 \mathrm{~F}_{1}$ hybrids and two controls (Black King and La'ala hybrids) for plant height, number of branches , flowering date, Average fruit weight and Fruit length traits are presented in Table (1). Regarding plant height, the findings indicated that a significant differences among different parental genotypes and $\mathrm{F}_{1}$ hybrids. Concerning plant height the data showed that the plant height of parental genotypes ranged from 42.66 $\left(\mathrm{P}_{6}\right)$ to $60.33 \mathrm{~cm}\left(\mathrm{P}_{5}\right)$ with the mean of $50.49 \mathrm{~cm}$, as compared to the hybrids $\mathrm{F}_{1}$ which ranged from $48.00\left(\mathrm{P}_{2} \times \mathrm{P}_{4}\right)$ to $78.00 \mathrm{~cm}\left(\mathrm{P}_{3} \times \mathrm{P}_{6}\right)$ with the mean of $58.28 \mathrm{~cm}$. Regarding the parental genotypes, the Black beauty $\left(\mathrm{P}_{3}\right)$ and PI $470273\left(\mathrm{P}_{5}\right)$ had the highest plant height value and were significantly different from all other parental genotypes. Additionally, the genotypes Local cultivar white long $\left(\mathrm{P}_{1}\right)$ and Local cultivar dark long $\left(\mathrm{P}_{2}\right)$ ranked second in this trait. Meanwhile, the genotypes $\left(\mathrm{P}_{4}\right)$ and $\left(\mathrm{P}_{6}\right)$ showed the lowest significant value for this trait $(42.00 \mathrm{~cm})$. Similarly, in the case of hybrids, the hybrid $\left(\mathrm{P}_{3} \times \mathrm{P}_{6}\right)$ had the highest plant height and was significantly different from all other hybrids. Likewise, the hybrids $\left(\mathrm{P}_{2} \times \mathrm{P}_{3}\right),\left(\mathrm{P}_{5} \times \mathrm{P}_{6}\right)$ and $\left(\mathrm{P}_{1} \times \mathrm{P}_{3}\right)$ ranked second in this trait. Meanwhile, the lowest plant height showed in the hybrid $\left(\mathrm{P}_{2} \times \mathrm{P}_{4}\right)$, but it wasn't significantly different from the most of hybrids and the two controls. These results coincided with those of Roychowdhury et al., (2011) who reported that the analysis of variance revealed highly significant differences among ten genotypes of eggplant for all the quantitative characters studied i.e., plant height and Hamada et al., (2016) who found that the parental genotype Balady dark long showed the highest means for plant height $(61.63 \mathrm{~cm})$ compared to the remaining genotypes. Also, they reported that the hybrid Balady dark long x Balady dark round obtained the highest means for plant height $(60.73 \mathrm{~cm})$ compared to the remaining genotypes.

As for the number of branches per plant, the recorded data indicated that a significant differences among different parental genotypes and $F_{1}$ hybrids. The number of branches per plant of parental genotypes ranged from $8.33\left(\mathrm{P}_{1}\right)$ to $14.33\left(\mathrm{P}_{4}\right)$ with the mean of 10.77 , as compared to the $\mathrm{F}_{1}$ hybrids which ranged from $11.33\left(\mathrm{P}_{1} \times \mathrm{P}_{2}\right)$ to 25.00 $\left(\mathrm{P}_{4} \times \mathrm{P}_{6}\right)$ with the mean of 17.77. Regarding the parental genotypes, the PI $408974\left(\mathrm{P}_{4}\right)$ had the highest value of number of branches per plant. The hybrid $\left(\mathrm{P}_{4} \times \mathrm{P}_{6}\right)$ had the highest number of branches per plant, but it 
wasn't significantly different from hybrids $\left(\mathrm{P}_{4} \times \mathrm{P}_{5}\right),\left(\mathrm{P}_{2} \times \mathrm{P}_{6}\right)$ and $\left(\mathrm{P}_{2} \times\right.$ $\left.\mathrm{P}_{4}\right)$. Likewise, the hybrids $\left(\mathrm{P}_{5} \times \mathrm{P}_{6}\right)$ ranked second in this trait, but it wasn't significantly different from hybrids $\left(\mathrm{P}_{2} \times \mathrm{P}_{6}\right)$ and $\left(\mathrm{P}_{2} \times \mathrm{P}_{4}\right)$. Whereas, the lowest number of branches per plant showed in the hybrid Black King (used as control), but it wasn't significantly different from the hybrids $\left(\mathrm{P}_{2} \times \mathrm{P}_{3}\right)$ and $\left(\mathrm{P}_{1} \times \mathrm{P}_{2}\right)$.

Table 1: Mean performance for some vegetative growth and flowering traits of different eggplant parental genotypes and their $F_{1}$ hybrids evaluated in the open field during the 2018 summer season.

\begin{tabular}{|c|c|c|c|c|c|}
\hline Genotypes $^{\text {z }}$ & $\begin{array}{l}\begin{array}{l}\text { Plant height } \\
(\mathrm{cm})\end{array} \\
\end{array}$ & $\begin{array}{l}\text { No. of } \\
\text { branches/plant }\end{array}$ & $\begin{array}{l}\text { Flowering } \\
\text { date (day) }\end{array}$ & $\begin{array}{l}\text { Average fruit } \\
\text { weight }(\mathrm{g}))\end{array}$ & $\begin{array}{l}\text { Fruit length } \\
(\mathrm{cm})\end{array}$ \\
\hline $\mathbf{P}_{1}$ & 50.66 fghi & $8.33 \mathrm{k}$ & 70.33 cde & 54.00 jk & 13.92 defg \\
\hline${ }_{2} \mathbf{P}$ & 49.00hij & 11.00hijk & 71.66 bcd & 74.20 fghij & 12.74 fghij \\
\hline${ }_{3} \mathbf{P}$ & 60.33cde & 12.33ghijk & 70.00 cde & $210.00 \mathrm{ab}$ & $11.267 \mathrm{k}$ \\
\hline${ }_{4} \mathbf{P}$ & $42.66 \mathrm{j}$ & 14.33efgh & $60.33 i \mathbf{j}$ & $34.41 \mathrm{k}$ & 13.59 efgh \\
\hline${ }_{5} \mathrm{P}$ & 60.33cde & $9.33 \mathrm{jk}$ & $79.66 \mathrm{a}$ & 80.40 fghi & 12.66 ghijk \\
\hline${ }_{6} \mathbf{P}$ & $42.66 \mathbf{j}$ & $9.33 \mathrm{jk}$ & 66.00efgh & 95.97 defg & 7.40 \\
\hline Mean & 50.49 & 10.77 & 69.66 & 91.49 & 11.29 \\
\hline${ }_{2} \mathbf{P} \times{ }_{1} \mathbf{P}$ & 57.00defg & 11.33 hijk & 72.00 bc & 96.96 def & 15.37 abcd \\
\hline $\mathbf{P}_{1} \times \mathbf{P}_{3}$ & 65.66 bc & $18.66 \mathrm{~cd}$ & $73.00 \mathrm{~b}$ & $115.65 \mathrm{~d}$ & 15.65 abc \\
\hline $\mathbf{P}_{1} \times \mathbf{P}_{4}$ & 56.00defgh & 18.33 cde & 67.00 def & $62.90 \mathrm{ij}$ & $16.85 \mathrm{a}$ \\
\hline $\mathbf{P}_{1} \times \mathbf{P}_{5}$ & 56.33defgh & 13.66 fghi & $75.66 \mathrm{ab}$ & 64.19 hij & 14.17 cdef \\
\hline $\mathbf{P}_{1} \times \mathbf{P}_{6}$ & 52.00 fghi & 13.33fghij & 69.66 cde & $62.84 \mathrm{ij}$ & 12.37 hijk \\
\hline $\mathbf{P}_{2} \times \mathbf{P}_{3}$ & $69.33 \mathrm{~b}$ & 11.33 hijk & 67.00 def & $156.87 \mathrm{c}$ & 12.74 fghijk \\
\hline $\mathbf{P}_{2} \times \mathbf{P}_{4}$ & $48.00 \mathrm{ij}$ & 22.00 abc & $59.33 \mathbf{j}$ & 73.33 fhhij & 15.63 abc \\
\hline $\mathbf{P}_{2} \times \mathbf{P}_{5}$ & 53.33 efghi & 16.00defg & $66.66 \mathrm{efg}$ & 79.83fghi & 12.71 fghijk \\
\hline $\mathbf{P}_{2} \times \mathbf{P}_{6}$ & 49.33 ghij & $23.33 \mathrm{ab}$ & $59.33 \mathrm{j}$ & $157.66 \mathrm{c}$ & 14.20 cdef \\
\hline $\mathbf{P}_{3} \times \mathbf{P}_{4}$ & 54.66defghi & 18.33 cde & 62.00 ghij & $105.53 \mathrm{de}$ & 12.85 fghi \\
\hline $\mathbf{P}_{3} \times \mathbf{P}_{5}$ & 51.00 fghi & $14.00 \mathrm{fgh}$ & 58.33 j & 80.71 fghi & 13.98 defg \\
\hline $\mathbf{P}_{3} \times \mathbf{P}_{6}$ & 78.00 a & 17.00 def & 64.33fghi & $189.25 \mathrm{~b}$ & $11.28 \mathbf{j k}$ \\
\hline $\mathbf{P}_{4} \times \mathbf{P}_{5}$ & $62.00 \mathrm{bcd}$ & $24.33 \mathrm{a}$ & 59.33 j & 64.72 hij & 15.32 bcd \\
\hline $\mathbf{P}_{4} \times \mathbf{P}_{6}$ & 52.33 fghi & 25.00 a & 61.66 hij & 73.54 ghij & 14.59 cde \\
\hline $\mathbf{P}_{5} \times \mathbf{P}_{6}$ & $69.33 \mathrm{~b}$ & 20.00 bcd & 72.00 bc & $148.52 \mathrm{c}$ & 12.85 fghi \\
\hline Mean & 58.28 & 17.77 & 65.81 & 102.16 & 14.03 \\
\hline Black King & 50.16 ghij & 9.50 ijk & 72.33 bc & 217.68 a & 11.69 ijk \\
\hline Laala & 54.66defghi & 18.50 cde & 66.00efgh & $69.41 \mathrm{hij}$ & 13.60 efgh \\
\hline Mean & 52.41 & 14.00 & 69.17 & 124.46 & 13.83 \\
\hline $\operatorname{LSD}(0.05)$ & 7.67 & 4.29 & 4.96 & 23.25 & 1.48 \\
\hline
\end{tabular}

These results matched with those of Roychowdhury et al., (2011) who reported that the analysis of variance revealed highly significant differences among ten genotypes of eggplant for all the quantitative characters studied i.e., number of branches/plant and Hamada et al., (2016) who found that the parental genotype Balady dark long showed the highest means for number of branches (8.27) compared to the remaining genotypes. While, they had contradiction when reported that the hybrid Balady dark round $\mathrm{x}$ Balady dark long showed the highest 
means for number of branches (8.93)compared to the remaining genotypes.

Referring flowering date (Table,1), the results indicated that a significant differences among different parental genotypes and $F_{1}$ hybrids in this trait (the number of days from planting date to first flower anthesis). The data showed that the number of days from planting date to first flower anthesis of parental genotypes ranged from $60.33\left(\mathrm{P}_{4}\right)$ to 79.66 days $\left(\mathrm{P}_{5}\right)$ with the mean of 69.66 days, as compared to the hybrids $\mathrm{F}_{1}$ which ranged from $58.33\left(\mathrm{P}_{3} \times \mathrm{P}_{5}\right)$ to 75.66 days $\left(\mathrm{P}_{1} \times \mathrm{P}_{5}\right)$ with the mean of 65.81 days. With respect to parental genotypes, the genotype PI $408974\left(\mathrm{P}_{4}\right)$ was the earliest in the flowers anthesis and was significantly different from all other parental genotypes. Likewise, the PI $542612\left(\mathrm{P}_{6}\right)$ ranked second in this trait and significantly different from all other parental genotypes. Meanwhile, the genotype PI $470273\left(\mathrm{P}_{5}\right)$ was the tardiest in the flowers anthesis and significantly different from all other parental genotypes. Similarly, in the case of hybrids, the hybrid $\left(\mathrm{P}_{3} \times \mathrm{P}_{5}\right)$ was the earliest in the flowers anthesis), but it wasn't significantly different from hybrids $\left(\mathrm{P}_{2} \times \mathrm{P}_{4}\right),\left(\mathrm{P}_{2} \times \mathrm{P}_{6}\right),\left(\mathrm{P}_{3} \times \mathrm{P}_{4}\right),\left(\mathrm{P}_{4} \times \mathrm{P}_{5}\right)$ and $\left(\mathrm{P}_{4} \times\right.$ $\left.\mathrm{P}_{6}\right)$. On the contrary, the hybrid Local cultivar white long $\left(\mathrm{P}_{1} \times \mathrm{P}_{5}\right)$ was the tardiest in the flowers anthesis, but it wasn't significantly different from hybrids $\left(\mathrm{P}_{1} \times \mathrm{P}_{2}\right),\left(\mathrm{P}_{1} \times \mathrm{P}_{3}\right),\left(\mathrm{P}_{5} \times \mathrm{P}_{6}\right)$ and Black King (used as control).

Regarding average fruit weight trait (Table1), the findings indicated that there were significant differences among different parental genotypes and $F_{1}$ hybrids. Concerning average Fruit weight trait the obtained data showed that the average fruit weight of parental genotypes ranged from $34.41\left(\mathrm{P}_{4}\right)$ to $210.00 \mathrm{~g}\left(\mathrm{P}_{3}\right)$ with the mean of $91.49 \mathrm{~g}$, as compared to the hybrids $\mathrm{F}_{1}$ which ranged from $62.84\left(\mathrm{P}_{1} \times \mathrm{P}_{6}\right)$ to 189.25 $\mathrm{g}\left(\mathrm{P}_{3} \times \mathrm{P}_{6}\right)$ with the mean of $102.16 \mathrm{gm}$. Regarding the parental genotypes, the Black beauty $\left(\mathrm{P}_{3}\right)$ had the highest average fruit weight and was significantly different from all other parental genotypes. On the other hand, the genotype PI $408974\left(\mathrm{P}_{4}\right)$ showed the lowest average fruit weight, but it wasn't significantly different from the genotype Local cultivar white long $\left(\mathrm{P}_{1}\right)$. In the case of hybrids, the hybrid $\left(\mathrm{P}_{3} \times \mathrm{P}_{6}\right)$ had the highest significant average fruit weight. Whereas, the lowest average fruit weight was measured in the hybrid $\left(\mathrm{P}_{1} \times \mathrm{P}_{6}\right)$, but it wasn't significantly different from the most of hybrids and La'ala hybrid (used as control).

Referring Fruit length, the results presented in Table 1 indicated that there were significant differences among different parental genotypes and $F_{1}$ hybrids. Concerning fruit length the data showed that the fruit length of parental genotypes ranged from $7.40\left(\mathrm{P}_{6}\right)$ to $13.92 \mathrm{~cm}$ $\left(\mathrm{P}_{1}\right)$ with the mean of $11.29 \mathrm{~cm}$, as compared to the hybrids $F_{1}$ which 
ranged from $11.28\left(\mathrm{P}_{3} \times \mathrm{P}_{6}\right)$ to $16.85 \mathrm{~cm}\left(\mathrm{P}_{1} \times \mathrm{P}_{4}\right)$ with the mean of 14.03 $\mathrm{cm}$. The Local cultivar white long $\left(\mathrm{P}_{1}\right)$ give the longest fruits, but it wasn't significantly different from genotypes PI408974 $\left(\mathrm{P}_{4}\right)$ and Local cultivar dark long $\left(\mathrm{P}_{2}\right)$ and were significantly different from all other parental genotypes, In the case of hybrids, the hybrid $\left(\mathrm{P}_{1} \times \mathrm{P}_{4}\right)$ had the longest significant value for this trait, but it wasn't significantly different from hybrid $\left(\mathrm{P}_{2} \times \mathrm{P}_{4}\right)$. Whereas, the shortest fruit length showed in the hybrid $\left(\mathrm{P}_{3} \times \mathrm{P}_{6}\right)$ was value $(11.28 \mathrm{~cm})$ but it wasn't significantly different from hybrids $\left(\mathrm{P}_{1} \times \mathrm{P}_{6}\right),\left(\mathrm{P}_{2} \times \mathrm{P}_{5}\right)$ and $\left(\mathrm{P}_{2} \times \mathrm{P}_{3}\right)$, were values (12.37, 12.71 and $12.74 \mathrm{~cm}$, respectively).

Concerning fruit diameter (Table, 2) the data showed that fruit diameter of parental genotypes ranged from $1.79\left(\mathrm{P}_{4}\right)$ to $6.00 \mathrm{~cm}\left(\mathrm{P}_{6}\right)$ with the mean of $3.46 \mathrm{~cm}$, as compared to the hybrids $F_{1}$ which ranged from 2.23 to $7.24 \mathrm{~cm}$ with the mean of $3.73 \mathrm{~cm}$. Mean of $F_{1}$ was larger little than mean of parents for fruit diameter. The PI $542612\left(\mathrm{P}_{6}\right)$ had the highest value for fruit diameter, and was significantly different from all other parental genotypes. Likewise, the Black beauty $\left(\mathrm{P}_{3}\right)$ ranked second in this trait and significantly different from all other parental genotypes. Whereas genotype $\left(\mathrm{P}_{1}\right)$ showed the lowest significant value for fruit diameter, but it wasn't significantly different from genotype $\left(\mathrm{P}_{5}\right)$. The cross $\left(\mathrm{P}_{3} \times \mathrm{P}_{6}\right)$ gave the largest value $(7.24 \mathrm{~cm})$ were significantly different from all other hybrids, but one hybrid from hybrids control (Black king) wasn't significantly different for the same trait. On the contrary, the hybrid $\left(\mathrm{P}_{1} \times \mathrm{P}_{4}\right)$ recorded the lowest value $(2.23 \mathrm{~cm})$ it wasn't significantly different for the hybrids $\left(\mathrm{P}_{1} \times \mathrm{P}_{5}\right),\left(\mathrm{P}_{4} \times \mathrm{P}_{5}\right),\left(\mathrm{P}_{2} \times \mathrm{P}_{4}\right)$, $\left(\mathrm{P}_{1} \times \mathrm{P}_{6}\right)$ and $\left(\mathrm{P}_{4} \times \mathrm{P}_{6}\right)$.

Regarding number of fruit/plant, the findings indicated that there were significant differences among different parental genotypes and $F_{1}$ hybrids. Concerning number of fruit /plant the data in Table 2 showed that the number of fruit /plant of parental genotypes ranged from 9.67 $\left(\mathrm{P}_{3}\right)$ to $54.00\left(\mathrm{P}_{4}\right)$ with the mean of 18.83 , as compared to the hybrids $\mathrm{F}_{1}$ which ranged from $8.67\left(\mathrm{P}_{1} \times \mathrm{P}_{3}\right)$, to $48.33\left(\mathrm{P}_{1} \times \mathrm{P}_{4}\right)$, with the mean of 22.199. The case of, hybrids, the hybrid $\left(\mathrm{P} 1 \times\left(\mathrm{P}_{4}\right)\right.$ had the highest number of fruit /plant value and was significantly different from all other hybrids, except the hybrid $\left(\mathrm{P}_{4} \times \mathrm{P}_{5}\right)$ and one hybrid from control. In contrast the hybrid $\left(\mathrm{P}_{1} \times \mathrm{P}_{3}\right)$ had the lowest number of fruit /plant value and wasn't significantly different from most other hybrids such as $\left(\mathrm{P}_{1} \times\right.$ $\left.\mathrm{P}_{6}\right),\left(\mathrm{P}_{5} \times \mathrm{P}_{6}\right),\left(\mathrm{P}_{4} \times \mathrm{P}_{6}\right),\left(\mathrm{P}_{2} \times \mathrm{P}_{3}\right)$ and $\left(\mathrm{P}_{2} \times \mathrm{P}_{5}\right)$.

The results presented in Table 2 indicated that a significant differences among different parental genotypes and $F_{1}$ hybrids. Concerning fruit yield per plant the data showed that the fruit yield per plant of parental genotypes ranged from $0.77\left(\mathrm{P}_{2}\right)$ to $2.36 \mathrm{~kg}\left(\mathrm{P}_{4}\right)$ with the mean of $1.267 \mathrm{~kg}$, as compared to the hybrids $\mathrm{F}_{1}$ which ranged from 1.28 
$\left(\mathrm{P}_{2} \times \mathrm{P}_{5}\right)$ to $4.02 \mathrm{~kg}\left(\mathrm{P}_{3} \times \mathrm{P}_{4}\right)$ with the mean of 2.40 . The PI $408974\left(\mathrm{P}_{4}\right)$ had the highest fruit yield per plant value and was significantly different from all other parental genotypes, whereas the genotype $\left(\mathrm{P}_{2}\right)$ was lowest value and wasn't significantly different for $\left(\mathrm{P}_{1}\right)$. Concerning crosses, $\left(\mathrm{P}_{3}\right.$ $\left.\times \mathrm{P}_{4}\right)$ had highest value followed by $\left(\mathrm{P}_{3} \times \mathrm{P}_{6}\right),\left(\mathrm{P} 4 \times \mathrm{P}_{5}\right)$ and $\left(\mathrm{P}_{2} \times \mathrm{P}_{4}\right)$, respectively, however, the cross $\left.\left(\mathrm{P}_{2}\right) \times \mathrm{P}_{5}\right)$ had the lowest for fruit yield per plant value and wasn't significantly different from crosses $\left(\mathrm{P}_{1} \times \mathrm{P}_{2}\right)$, $\left(\mathrm{P}_{1} \times \mathrm{P}_{3}\right)$, Local cultivar white long $\left(\mathrm{P}_{1} \times \mathrm{P} 6\right)$.

Table 2: Mean performance for some fruit characters of different eggplant parental genotypes and their $F_{1}$ hybrids evaluated in the open field during the 2018 summer season

\begin{tabular}{|c|c|c|c|c|}
\hline Genotypes & Fruit diameter (cm) & No. of fruit /plant & & $\begin{array}{l}\text { Fruit yield kg/ } \\
\text { plant }\end{array}$ \\
\hline $\mathbf{P}_{1}$ & $2.25 \quad k$ & 11.67 & 0.89 & hi \\
\hline $\mathbf{P}_{2}$ & 2.91 hi & 13.33 & 0.77 & $\mathbf{i}$ \\
\hline $\mathbf{P}_{3}$ & 5.16 c & 9.67 & 1.21 & fghi \\
\hline $\mathbf{P}_{4}$ & $1.79 \quad 1$ & 54.00 & 2.36 & cdef \\
\hline $\mathbf{P}_{5}$ & $2.66 \quad$ ijk & 14.00 & 1.06 & ghi \\
\hline $\mathbf{P}_{6}$ & $6.00 \quad$ b & 10.33 & 1.13 & fghi \\
\hline Mean & 3.46 & 18.83 & 1.27 & \\
\hline $\mathbf{P}_{1} \times \mathbf{P}_{2}$ & 3.42 fg & 26.33 efg & 1.30 & efghi \\
\hline $\mathbf{P}_{1} \times \mathbf{P}_{3}$ & $3.23 \mathrm{gh}$ & 8.67 & 1.38 & efghi \\
\hline $\mathbf{P}_{1} \times \mathbf{P}_{4}$ & $2.23 \quad \mathrm{kl}$ & 48.33 & 2.57 & bcde \\
\hline $\mathbf{P}_{1} \times \mathbf{P}_{5}$ & \begin{tabular}{|ll}
2.33 & jk \\
\end{tabular} & 22.00 fgh & 1.79 & defghi \\
\hline $\mathbf{P}_{1} \times \mathbf{P}_{6}$ & $2.56 \quad$ ijk & 9.33 & 1.43 & efghi \\
\hline $\mathbf{P}_{2} \times \mathbf{P}_{3}$ & 6.01 b & 14.33 & 1.98 & defghi \\
\hline $\mathbf{P}_{2} \times \mathbf{P}_{4}$ & $2.53 \quad$ ijk & 35.33 & 3.61 & abc \\
\hline $\mathbf{P}_{2} \times \mathbf{P}_{5}$ & 3.56 efg & 16.33 & 1.28 & efghi \\
\hline $\mathbf{P}_{2} \times \mathbf{P}_{6}$ & $4.20 \mathrm{~d}$ & 22.00 fgh & 2.89 & abcd \\
\hline $\mathbf{P}_{3} \times \mathbf{P}_{4}$ & 3.98 de & 28.00 & 4.02 & $\mathbf{a}$ \\
\hline $\mathbf{P}_{3} \times \mathbf{P}_{5}$ & 3.98 de & 22.00 & 2.34 & cdefg \\
\hline $\mathbf{P}_{3} \times \mathbf{P}_{6}$ & $\begin{array}{ll}7.24 & \mathrm{a} \\
\end{array}$ & 20.33 & 3.89 & $\mathbf{a b}$ \\
\hline $\mathbf{P}_{4} \times \mathbf{P}_{5}$ & $2.45 \quad$ jk & 41.00 & 3.87 & ab \\
\hline $\mathbf{P}_{4} \times \mathbf{P}_{6}$ & $\begin{array}{ll}2.66 & \text { ijk } \\
\end{array}$ & 10.00 & 2.18 & defgh \\
\hline $\mathbf{P}_{5} \times \mathbf{P}_{6}$ & $\begin{array}{ll}5.66 & \text { b } \\
\end{array}$ & 9.33 & 1.59 & efghi \\
\hline Mean & 3.73 & 22.20 & 2.40 & \\
\hline Black King & $7.13 \quad \mathrm{a}$ & 12.33 hij & 2.43 & cdef \\
\hline La'ala & $2.75 \quad \mathrm{ij}$ & 38.00 & 2.91 & abcd \\
\hline Mean & 4.53 & 25.17 & 2.67 & \\
\hline LSD(0.05) & 0.44 & 10.68 & 1.30 & \\
\hline
\end{tabular}

These results matched with those of Hamada et al., (2016) who found that the parental genotype Balady dark long $\left(\mathrm{P}_{3}\right)$ showed the highest means for total fruit yield (44.93 ton/feddan) compared to other genotypes. Also, they stated that the hybrid (Balady dark long x Balady dark round) obtained the highest means for total fruit yield (58.03ton/feddan) and showed that the hybrid (Balady white long $\mathrm{x}$ Balady dark round) exhibited positive and highly significant heterosis values relative to their mid-parents and better parent for total fruit yield. 


\section{Heterosis effects}

Data in Table (3) show heterosis over mid and better-parent for 15 $\mathrm{F}_{1}$ hybrids. All the crosses exhibited significant mid and better-parent heterosis for majority of the traits indicating predominance of nonadditive gene action in genetic control of these traits.

Regarding plant height, estimates of mid parent (MP) and better parent (BP) heterosis of crosses are presented in Table 3: Showed that 9 crosses out of the 15 evaluated $F_{1}$ hybrids indicated highly significant positive mid-parent heterosis, and one hybrid recorded significant negative value was $\left(\mathrm{P}_{2} \times \mathrm{P}_{6}\right)$ with $(-15.70 \%)$. Mid - parent heterosis ranged from $-15.70 \%$ for the $\left(\mathrm{P}_{3} \times \mathrm{P}_{5}\right)$ to $50.97 \%$ for the cross $\left(\mathrm{P}_{3} \times \mathrm{P}_{6}\right)$. Desirable positive BP heterosis for plant height was observed in six $\mathrm{F}_{1}$ crosses, One $\mathrm{F}_{1}$ crosses exhibited desirable significant negative $\mathrm{BP}$ values, i.e. $\left(\mathrm{P}_{3} \times \mathrm{P}_{5}\right)$ with $(-15.93 \%)$, Concerning heterosis over standard check in Table (4), exhibited 4 crosses out of the 6 evaluated $F_{1}$ hybrids concerning standard check (a) indicated significant standard check heterosis, and ranged from $-12.2 \%$ for the cross $\left(\mathrm{P}_{2} \times \mathrm{P}_{4}\right)$ to $13.41 \%$ for the cross $\left(\mathrm{P}_{4} \times \mathrm{P}_{5}\right)$, while exhibited 8 crosses out of the 9 evaluated $\mathrm{F}_{1}$ hybrids indicated significant standard check heterosis (b), and ranged from $-1.66 \%$ for the cross $\left(\mathrm{P}_{2} \times \mathrm{P}_{6}\right)$ to $55.48 \%$ for the cross $\left(\mathrm{P}_{3} \times \mathrm{P}_{6}\right)$ for standard check heterosis (b).

Table 3: Percentage of heterosis in the $F_{1}$ generations over both mid and better parents for some vegetative growth and flowering traits of 15 eggplant $F_{1}$ hybrids

\begin{tabular}{|c|c|c|c|c|c|c|}
\hline \multirow[b]{2}{*}{ Crosses } & \multicolumn{2}{|c|}{ Plant height } & \multicolumn{2}{|c|}{ Number of branches } & \multicolumn{2}{|c|}{ Flowering date } \\
\hline & М.P\% & B.P(\%) & М.P(\%) & B.P(\%) & M.P(\%) & B.P(\%) \\
\hline $\mathbf{P}_{1} \times \mathbf{P}_{2}$ & $14.38^{* * *}$ & $12.50^{* *}$ & $17.24^{* *}$ & 3.03 & 1.41 & 2.37 \\
\hline $\mathbf{P}_{1} \times \mathbf{P}_{3}$ & $17.96^{* *}$ & $8.24^{*}$ & $80.65^{* *}$ & $51.35^{* *}$ & 4.04 & 4.29 \\
\hline $\mathbf{P}_{1} \times \mathbf{P}_{4}$ & $20.00^{* *}$ & $10.53^{* *}$ & $61.76^{* *}$ & $27.91^{* *}$ & 2.55 & $11.05^{* *}$ \\
\hline $\mathbf{P}_{1} \times \mathbf{P}_{5}$ & 1.50 & -6.63 & $54.72^{* *}$ & $46.43^{* *}$ & 0.89 & $\mathbf{7 . 5 8} 8^{* *}$ \\
\hline $\mathbf{P}_{1} \times \mathbf{P}_{6}$ & $11.43^{* *}$ & 2.63 & $50.94^{* *}$ & $42.86^{* * *}$ & 2.20 & $5.56^{*}$ \\
\hline P2 $\times$ P3 & $26.44^{* *}$ & $14.29^{* * *}$ & -2.86 & -8.11 & $-5.41^{*}$ & -4.29 \\
\hline $\mathbf{P}_{2} \times \mathbf{P}_{4}$ & 4.73 & -2.04 & 73.68 ${ }^{* *}$ & $53.49^{* * *}$ & $-10.10^{* *}$ & -1.66 \\
\hline $\mathbf{P}_{2} \times \mathbf{P}_{5}$ & -2.44 & -11.60 & $57.38^{* * *}$ & $45.45^{* * *}$ & $-11.89^{* *}$ & $-6.98^{*}$ \\
\hline $\mathbf{P}_{2} \times \mathbf{P}_{6}$ & $7.64^{*}$ & 0.68 & $129.51^{* *}$ & $112.12^{* *}$ & $-13.80^{* * *}$ & $-10.10^{* *}$ \\
\hline $\mathbf{P}_{3} \times \mathbf{P}_{4}$ & 5.81 & -9.89 & $37.50^{* *}$ & $27.91^{* * *}$ & $-4.86^{*}$ & 2.76 \\
\hline $\mathbf{P}_{3} \times \mathbf{P}_{5}$ & -15.70 & -15.93 & $29.23^{* *}$ & $13.51^{* * *}$ & $-22.05^{* *}$ & $-16.67^{* *}$ \\
\hline $\mathbf{P} 3 \times \mathbf{P}_{6}$ & $50.97^{* *}$ & $28.57^{* * *}$ & $56.92^{* *}$ & $37.84^{* * *}$ & $-5.39^{*}$ & -2.53 \\
\hline $\mathbf{P}_{4} \times \mathbf{P}_{5}$ & $20.39^{* *}$ & 2.76 & $105.63 * *$ & $69.77^{* *}$ & $-15.24^{* * *}$ & -1.66 \\
\hline$\overline{\mathbf{P}_{4} \times \mathbf{P}_{6}}$ & $22.66^{* *}$ & $22.66^{* *}$ & $111.27 * *$ & $74.42^{* *}$ & -2.37 & 2.21 \\
\hline $\mathbf{P}_{5} \times \mathbf{P}_{6}$ & $34.63^{* *}$ & $14.92^{* *}$ & $114.29 * *$ & $114.29^{* * *}$ & -1.14 & $9.09^{* *}$ \\
\hline LCD 5\% & 6.27 & 7.24 & 3.99 & 4.60 & 4.61 & 5.32 \\
\hline LCD 1\% & 8.40 & 9.69 & 5.33 & 6.16 & 6.17 & 7.12 \\
\hline
\end{tabular}

$\mathrm{Z} *$ significant and $* *$ highly significant at 0.05 and 0.01 levels of probability, respectively. 
Table 4: Percentage of heterosis values standard checks $\left(\text { La'ala }_{a}\right)^{\mathrm{z}}$ and $\left(\text { Black king }{ }_{b}\right)^{z}$ for some vegetative growth and flowering traits of 6 eggplant $F_{1}$ hybrids.

\begin{tabular}{|c|c|c|c|}
\hline \multirow{2}{*}{ Crosses $^{\mathrm{Z}}$} & Plant height (cm) & Number of branches & Flowering date (day) \\
\hline & Standard checks & Standard checks & Standard checks \\
\hline $\mathbf{P 1} \times \mathbf{P 2}$ & $4.27_{\mathrm{a}}$ & $-38.74_{a}$ & $9.09_{\mathrm{a}}$ \\
\hline P1 $\times$ P4 & $2.44_{a}$ & $-0.9_{\mathrm{a}}$ & $1.52_{\mathrm{a}}$ \\
\hline $\mathrm{P} 1 \times \mathrm{P5}$ & $3.05_{a}$ & $-26.12 \mathrm{a}$ & $14.65_{a}$ \\
\hline $\mathbf{P} 2 \times \mathrm{P4}$ & $-12.2_{\mathrm{a}}$ & $18.92 a$ & $-10.1_{a}$ \\
\hline P2 $\times$ P5 & $-2.45_{a}$ & $-13.51_{a}$ & $1.01_{\mathrm{a}}$ \\
\hline $\mathrm{P} 4 \times \mathrm{P5}$ & $13.41_{a}$ & $31.53 \mathrm{a}$ & $-10.11_{a}$ \\
\hline P1 $\times$ P3 & $30.9_{b}$ & $96.49_{b}$ & $0.93_{\mathrm{b}}$ \\
\hline P1 $\times$ P6 & $3.65_{b}$ & $40.35_{b}$ & $-3.68_{b}$ \\
\hline $\mathbf{P 2} \times \mathbf{P 3}$ & $38.2_{\mathrm{b}}$ & $19.29_{b}$ & $-7.37_{b}$ \\
\hline $\mathrm{P} 2 \times \mathrm{P} 6$ & $-1.66_{b}$ & $145.61_{b}$ & $-17.97_{b}$ \\
\hline P3×P4 & $8.97_{b}$ & $92.98_{b}$ & $-14.28_{b}$ \\
\hline $\mathrm{P3} \times \mathrm{P5}$ & $1.66_{b}$ & $47.37_{b}$ & $-19.35_{b}$ \\
\hline P3 $\times$ P6 & $55.48_{b}$ & $78.95_{b}$ & $-11.06_{b}$ \\
\hline $\mathbf{P 4} \times \mathbf{P 6}$ & $4.31_{b}$ & $163.16_{b}$ & $-14.74_{b}$ \\
\hline P5 $\times$ P6 & $38.2_{b}$ & $110.53_{b}$ & $-0.46_{b}$ \\
\hline
\end{tabular}

$\mathrm{Z}$ a standard check Lal, la hybrid long fruit and b Black King hybrid round fruit

These results coincided with those of Naresh et al., (2013) estimated significant positive heterosis for plant height, based on midparent, ranged from 0.83 to $29.74 \%$ in 36 crosses of eggplant and found that the maximum heterosis for this trait was exhibited by the crosses KS-6103 × KS-8822, KS-6103 × KS-8821 and KS-8504 ×KS-8821, and Hamada et al., (2016) who reported that the hybrid (Balady white long $\mathrm{x}$ Balady dark round) exhibited positive and highly significant heterosis.

Referring the number of branches per plant, estimates of mid and better-parent heterosis of crosses are presented in Table 3. Results Showed that 14 crosses out of the 15 evaluated F1 hybrids indicated highly significant positive for mid-parent heterosis, and ranged from $17.24 \%$ for the $\left(\mathrm{P}_{1} \times \mathrm{P}_{2}\right)$ to $129.51 \%$ for the cross $\left(\mathrm{P}_{2} \times \mathrm{P}_{6}\right)$. While, results showed that 13 crosses out of the 15 evaluated $F_{1}$ hybrids showed highly significant positive for better-parent heterosis, and ranged from $13.53 \%$ for the cross $\left(\mathrm{P}_{3} \times \mathrm{P}_{5}\right)$ to $112.12 \%$ for the cross $\left(\mathrm{P}_{2} \times\right.$ $\mathrm{P}_{6}$ ).Concerning heterosis over standard check in Table 4 exhibited 2 crosses out of the 6 evaluated F1 hybrids for standard check (a) indicated standard check heterosis, and ranged from $-38.74 \%$ for the cross $\left(\mathrm{P}_{1} \times\right.$ $\left.\mathrm{P}_{2}\right)$ to $31.53 \%$ for the cross $\left(\mathrm{P}_{4} \times \mathrm{P}_{5}\right)$. However, exhibited all $\mathrm{F}_{1}$ hybrids indicated positive standard check (b) heterosis for the number of 
branches per plant. These results coincided with those of Mahmoud (2014) stated that mid and better parents heterosis values ranged from 0.46 to $36.67 \%$ and 4.78 to $13.67 \%$, respectively, for number of branches per plant, and Naresh et al., (2014) who mentioned that positive heterosis over better parent ranged from 1.38 to $52.23 \%$ for number of branches per plant in eggplant hybrids.

Data obtained on the number of days from planting date to first flower anthesis of evaluated eggplant genotypes are presented in Table (3)In this regard, the number of days from planting date to first flower anthesis with negative values of heterosis or heterobeltiosis was considered to be better and desirable.

Results revealed that, 5 out of the 15 evaluated $F_{1}$ hybrids showed highly significant negative heterosis for over mid parent for number of days from planting date to first flower anthesis and three hybrids registered significant negative heterosis for over mid parent, and ranged from $-22.05 \%$ for the hybrid $\left(\mathrm{P}_{3} \times \mathrm{P}_{5}\right)$ to $-1.14 \%$ for the hybrid $\left(\mathrm{P}_{5} \times \mathrm{P}_{6}\right)$. Other wise, two hybrids i.e. $\left(\mathrm{P}_{3} \times \mathrm{P}_{5}\right)$ and $\left(\mathrm{P}_{2} \times \mathrm{P}_{6}\right)$ indicate highly significant negative values of heterosis over the better parent with $(-16.7$ and $-10.10 \%$, respectively).Heterosis over the better parent ranged from 16.67 for the hybrid $\left(\mathrm{P}_{3} \times \mathrm{P}_{5}\right)$ to $11.05 \%$ for the hybrid $\left(\mathrm{P}_{1} \times \mathrm{P}_{4}\right)$. In connection with, standard check heterosis indicates rustles in Table (4). Two out of the 6 hybrids evaluated $F_{1}$ hybrids for standard check (a) showed negative values for the number of days from planting date to first flower anthesis, and hybrid $\left(\mathrm{P}_{4} \times \mathrm{P}_{5}\right)$ had highly significant negative value. The date in table 3 showed that most hybrids significant negative values for the number of days from planting date to first flower anthesis to strand check (b). These results are in agreement with those of Sao and Mehta (2010) evaluated 48 hybrids along with their parents in line $\times$ tester design during rainy season 2004/2005. They reported that among the eleven attributes studied highly significant and negative heterosis for days to first flowering (-14.66\%), and Al-Hubaity (2013) reported that the heterosis values ranged from -4.33 to $7.33 \%$ for date of flowering.

Referring average of fruit weight, estimates of mid and betterparent heterosis of crosses are presented in Table (5). Results indicated that 6 crosses out of the 15 evaluated $F_{1}$ hybrids had highly significant positive for mid-parent heterosis, and ranged from $32.71 \%$ for the cross $\left(\mathrm{P}_{3} \times \mathrm{P}_{6}\right)$ to $85.30 \%$ for the cross $\left(\mathrm{P}_{2} \times \mathrm{P}_{6}\right)$. While 3 hybrids were $\left(\mathrm{P}_{2} \times\right.$ $\left(\mathrm{P}_{6}\right),\left(\mathrm{P}_{5} \times \mathrm{P}_{6}\right)$ and $\left(\mathrm{P}_{1} \times \mathrm{P}_{2}\right)$ showed highly significant positive betterparent heterosis. 
Highly significant positive better-parent heterosis was observed only on three cross i.e., $\left(\mathrm{P}_{1} \times \mathrm{P}_{2}\right),\left(\mathrm{P}_{5} \times \mathrm{P}_{6}\right)$ and $\left(\mathrm{P}_{2} \times \mathrm{P}_{6}\right)$ with $(30.67$, 54.76 and $64.28 \%$ ).With reference to, standard check heterosis indicate rustles in Table 6 defined 3 crosses out of the 6 evaluated $F_{1}$ hybrids were positive value for standard $\operatorname{check}(\mathrm{a})$, and ranged from $-9.12 \%$ for the cross Local cultivar white long (P1) $\times$ PI $408974(\mathrm{P} 4)$ to $40.10 \%$ for the cross Local cultivar white long $\left(\mathrm{P}_{1}\right) \times$ Local cultivar dark long $\left(\mathrm{P}_{2}\right)$ for the same standard check. Otherwise, data in Table 6 show standard heterosis (b) for $9 \mathrm{~F}_{1}$ hybrids. All the crosses exhibited negative value, for average fruit weight. These results are in agreement with those reported by Al-Hubaity (2013) who observed the heterosis values ranged from -14.74 to $41.74 \%$ for average fruit weight, and Mahmoud (2014) stated that mid parents heterosis values ranged from -17.16 to $11.99 \%$ for average fruit weight, and its maximum heterosis was estimated in the cross CLW.1-1 × CLW.4-2. Check.

Table 5: Percentage of heterosis in the $F_{1}$ over both mid and better parents for some physical characters of $15 \mathrm{~F}_{1}$ eggplant.

\begin{tabular}{|c|c|c|c|c|c|c|}
\hline \multirow[b]{2}{*}{ Genotype } & \multicolumn{2}{|c|}{ Average fruit weight } & \multicolumn{2}{|c|}{ Fruit length } & \multicolumn{2}{|c|}{ Fruit diameter } \\
\hline & M.P & B.P & M.P & B.P & M.P & M.P \\
\hline $\mathbf{P}_{1} \times \mathbf{P}_{2}$ & $51.26^{* *}$ & $30.67^{* *}$ & $15.25^{* *}$ & $10.49^{* * *}$ & $32.39^{* *}$ & $17.26^{* *}$ \\
\hline $\mathbf{P}_{1} \times \mathbf{P}_{3}$ & -12.38 & -44.93 & $24.29^{* *}$ & $12.46^{* * *}$ & -12.81 & -37.42 \\
\hline $\mathbf{P}_{1} \times \mathbf{P}_{4}$ & $42.29^{* *}$ & 16.49 & $22.54^{* * *}$ & $21.10^{* * *}$ & $10.73^{* *}$ & -0.59 \\
\hline $\mathbf{P}_{1} \times \mathbf{P}_{5}$ & -4.47 & -20.16 & $6.66^{* *}$ & $1.87^{*}$ & -5.22 & -12.63 \\
\hline $\mathbf{P}_{1} \times \mathbf{P}_{6}$ & -16.19 & -34.52 & $16.09^{* *}$ & -11.09 & -37.86 & -57.28 \\
\hline $\mathbf{P}_{2} \times \mathbf{P}_{3}$ & 10.40 & -25.30 & $6.02^{* *}$ & -0.21 & $48.78^{* *}$ & $16.39^{* * *}$ \\
\hline $\mathbf{P}_{2} \times \mathbf{P}_{4}$ & $36.88^{* *}$ & 0.18 & $18.63^{* * *}$ & $15.04^{* * *}$ & $7.65^{* * *}$ & -13.14 \\
\hline $\mathbf{P}_{2} \times \mathbf{P}_{5}$ & 3.28 & -0.70 & 0.00 & -0.39 & $27.76^{* *}$ & $22.29^{* *}$ \\
\hline $\mathbf{P}_{2} \times \mathbf{P}_{6}$ & $85.30^{* * *}$ & $64.28^{* *}$ & $40.83^{* * *}$ & $11.23^{* * *}$ & -5.79 & -30.00 \\
\hline $\mathbf{P}_{3} \times \mathbf{P}_{4}$ & -13.64 & -49.75 & $3.39^{* * *}$ & -5.45 & $14.61^{* *}$ & -22.84 \\
\hline $\mathbf{P}_{3} \times \mathbf{P}_{5}$ & -44.41 & -61.57 & $16.88^{* * *}$ & $10.42^{* *}$ & $1.62^{* * *}$ & -22.97 \\
\hline $\mathbf{P}_{3} \times \mathbf{P}_{6}$ & $23.71^{* * *}$ & -9.88 & $20.86^{* *}$ & 0.12 & $29.73^{* *}$ & $20.72^{* * *}$ \\
\hline $\mathbf{P}_{4} \times \mathbf{P}_{5}$ & 12.74 & -19.50 & $16.69^{* *}$ & $12.73^{* * *}$ & $10.25^{* *}$ & -7.88 \\
\hline $\mathbf{P}_{4} \times \mathbf{P}_{6}$ & 12.80 & -23.37 & $39.05^{* *}$ & $7.38^{* *}$ & -31.54 & -55.56 \\
\hline $\mathbf{P}_{5} \times \mathbf{P}_{6}$ & $68.42^{* *}$ & $54.76^{* * *}$ & $28.07^{* *}$ & 1.45 & $30.77^{* *}$ & -5.56 \\
\hline LCD 5\% & 17.32 & 20.00 & 1.26 & 1.46 & 0.40 & 0.46 \\
\hline LCD $1 \%$ & 23.17 & 26.76 & 1.69 & 1.95 & 0.54 & 0.62 \\
\hline
\end{tabular}

* significant and $* *$ highly significant at 0.05 and 0.01 levels of probability, respectively.

Data in Table 5 exhibited most hybrids highly significant positive values of heterosis over the mid-parent for fruit length. The hybrid $\left(\mathrm{P}_{2} \times\right.$ $\mathrm{P}_{6}$ ) had the highest value $(40.83 \%)$, while the hybrid $\left(\mathrm{P}_{3} \times \mathrm{P}_{4}\right)$ had the lowest one $(3.39 \%)$. Only one hybrid $\left(\mathrm{P}_{2} \times \mathrm{P}_{5}\right)$ did not have any heterosis for fruit length. Related the heterosis over the better parent, the hybrid $\left(\mathrm{P}_{1} \times \mathrm{P}_{4}\right)$ had the highly significant value $(21.10 \%)$, while the hybrid $\left(\mathrm{P}_{1} \times \mathrm{P}_{6}\right)$ had the lowest one $(-11.9 \%)$. As for, check heterosis indicate rustles in Table (6). Results showed 5 crosses out of the 6 
evaluated F1 hybrids for standard check (a) were positive value, and ranged from $-6.49 \%$ for the cross $\left(\mathrm{P}_{2} \times \mathrm{P}_{5}\right)$ to $23.92 \%$ for the $\left(\mathrm{P}_{1} \times \mathrm{P}_{4}\right)$. However, standard check heterosis (b) for $9 \mathrm{~F}_{1}$ hybrids. All the crosses exhibited positive value except the hybrid $\left(\mathrm{P}_{3} \times \mathrm{P}_{6}\right)$ was value $-3.53 \%$, whilst the hybrid $\left(\mathrm{P}_{1} \times \mathrm{P}_{3}\right)$ was highest value $33.84 \%$ for fruit length. This results is coincided with Makani et al., (2013) reported that significant positive heterosis, based on mid-parent and better parent in the cross GP$180 \times \mathrm{KS}-331$ reaching to $21.11 \%$ and $12.11 \%$, respectively, for average fruit length, and Naresh et al., (2013) found that average fruit length for eggplant of heterosis over mid- parent 6.04 to $72.73 \%$.

Table 6: Heterosis $(\%)$ values standard checks $\left(\mathrm{La}^{\prime} \mathrm{ala}_{\mathrm{a}}\right)^{\mathrm{z}}$ and $($ Black king $\left._{b}\right)^{z}$ for some physical characters of 6 eggplant $F_{1}$ hybrids.

\begin{tabular}{|c|c|c|c|}
\hline Genotypes $^{z}$ & Fruit weight (g) & Fruit length $(\mathrm{cm})$ & Fruit diameter $(\mathrm{cm})$ \\
\hline $\mathbf{P}_{1} \times \mathbf{P}_{2}$ & $40.10_{a}$ & $13.07_{\mathrm{a}}$ & $24.21_{\mathrm{a}}$ \\
\hline $\mathbf{P}_{1} \times \mathbf{P}_{4}$ & $-9.12_{a}$ & $23.92_{a}$ & $-18.76_{a}$ \\
\hline $\mathbf{P}_{1} \times \mathbf{P}_{5}$ & $-7.25_{a}$ & $4.24_{a}$ & $-15.37_{a}$ \\
\hline $\mathbf{P}_{2} \times \mathbf{P}_{4}$ & $7.40_{a}$ & $14.95_{\mathrm{a}}$ & $-7.99 a$ \\
\hline $\mathbf{P}_{2} \times \mathbf{P}_{5}$ & $15.34_{\mathrm{a}}$ & $-6.49 \mathrm{a}$ & $29.54_{a}$ \\
\hline $\mathbf{P}_{4} \times \mathbf{P}_{5}$ & $-6.49 \mathrm{a}$ & $12.65_{a}$ & $-10.77_{a}$ \\
\hline $\mathbf{P}_{1} \times \mathbf{P}_{3}$ & $-46.87_{b}$ & $33.84 A_{b}$ & $-54.67_{b}$ \\
\hline $\mathbf{P}_{1} \times \mathbf{P}_{6}$ & $-71.13_{b}$ & $5.82_{b}$ & $-64.07_{b}$ \\
\hline $\mathbf{P}_{2} \times \mathbf{P}_{3}$ & $-27.94_{b}$ & $8.95_{b}$ & $-15.70_{b}$ \\
\hline $\mathbf{P}_{2} \times \mathbf{P}_{6}$ & $-27.57_{b}$ & $21.44_{b}$ & $-41.12_{b}$ \\
\hline $\mathbf{P}_{3} \times \mathbf{P}_{4}$ & $-51.52_{b}$ & $9.89_{b}$ & $-44.11_{b}$ \\
\hline$\overline{\mathbf{P}_{3} \times \mathbf{P}_{5}}$ & $-62.92_{b}$ & $19.62_{b}$ & $-44.21_{b}$ \\
\hline $\mathbf{P}_{3} \times \mathbf{P}_{6}$ & $-13.06_{b}$ & $-3.53_{b}$ & $1.54_{b}$ \\
\hline $\mathbf{P}_{4} \times \mathbf{P}_{6}$ & $-66.22_{b}$ & $24.80_{b}$ & $-62.62_{b}$ \\
\hline $\mathbf{P}_{5} \times \mathbf{P}_{6}$ & $-31.77_{b}$ & $9.89_{b}$ & $-20.56 \mathrm{~b}$ \\
\hline
\end{tabular}

$\mathrm{Z}$ a standard check Lal,la hybrid long fruit and b Black King hybrid round fruit

Concerning, fruit diameter; estimates of mid and better-parent heterosis of crosses are presented in Table 5. Results exhibited that 10 crosses out of the 15 evaluated $F_{1}$ hybrids defined highly significant positive mid-parent heterosis, and ranged from $1.62 \%$ for the cross $\left(\mathrm{P}_{2} \times\right.$ $\left.\mathrm{P}_{5}\right)$ to $48.78 \%$ for the $\left(\mathrm{P}_{2} \times \mathrm{P}_{3}\right)$. However, results Showed that 4 hybrids out of the 15 evaluated F1 hybrids showed highly significant positive better-parent heterosis, and ranged from $16.39 \%$ for the cross Local cultivar white long $\left.\left(\mathrm{P}_{2}\right) \times \mathrm{P}_{3}\right)$ to $22.29 \%$ for the cross $\left(\mathrm{P}_{2} \times \mathrm{P}_{5}\right)$. In connection with, standard check heterosis indicates rustles in Table (6). Two out of the 6 evaluated $F_{1}$ hybrids showed positive values over hybrids (La'ala) standard $\operatorname{check}(\mathrm{a})$ heterosis and ranged from $-18.76 \%$ for the cross $\left(\mathrm{P}_{1} \times \mathrm{P}_{4}\right)$ to $29.54 \%$ for the cross $\left(\mathrm{P}_{2} \times \mathrm{P}_{5}\right)$. On the other hand, the date in table 6 showed that most hybrids negative values for fruit diameter, except the hybrid Black beauty $\left(\mathrm{P}_{3} \times \mathrm{P}_{6}\right)$. These results are in agreement with those reported by Patel $\boldsymbol{e t}$ al,. (2013) who estimated 
significant positive heterosis, based on mid-parent for average fruit diameter ranged from $-11.10 \%$ to $65.20 \%$, Seven crosses out of 21 crosses showed significantly positive heterosis for both traits.

Data presented in Table (7). indicated that, the magnitude of heterosis for no. of fruit per plant ranged from -68.91 for the hybrid $\left(\mathrm{P}_{4} \times \mathrm{P}_{6}\right)$ to $110.67 \%$ for the hybrid $\left(\mathrm{P}_{1} \times \mathrm{P}_{2}\right)$ and from -81.48 for the hybrid $\left(\mathrm{P}_{4} \times \mathrm{P}_{6}\right)$ to $97.50 \%$ for the hybrid $\left(\mathrm{P}_{1} \times \mathrm{P}_{2}\right)$ over mid- parent and better parent, respectively. Whereas, 9 out of the 15 hybrids and 5 out of the 15 hybrids exhibited significantly positive heterosis over mid- parent and better parent, respectively for no. of fruit per plant. The cross $\left(\mathrm{P}_{1} \times \mathrm{P}_{2}\right)$ followed by the cross $\left(\mathrm{P}_{3} \times \mathrm{P}_{6}\right),\left(\mathrm{P}_{2} \times \mathrm{P}_{6}\right)$ and $\left(\mathrm{P}_{3} \times \mathrm{P}_{5}\right)$ had exhibited desirable significant positive heterosis over mid- parent and better parent. On the contrary, 4 out of the 15 hybrids and 8 out of the 15 hybrids exhibited highly significantly negative heterosis over mid- parent and better parent, respectively for no. of fruit per plant. The cross $\left(\mathrm{P}_{4} \times \mathrm{P}_{6}\right)$ had the lowest negative value over both types of heterosis. With regard to, standard check heterosis indicates rustles in Table 8.2 out of the 6 evaluated $F_{1}$ hybrids increase positive over hybrids (La'ala) standard check (a) heterosis and ranged from $-57.03 \%$ for the cross $\left(\mathrm{P}_{2} \times \mathrm{P}_{5}\right)$ to $27.19 \%$ for the cross $\left(\mathrm{P}_{1} \times \mathrm{P}_{4}\right)$ no. of fruit per plant. On the other hand, The date in Table 8: showed that 5 out of the 9 evaluated $F_{1}$ hybrids increase positive over hybrids (Black king) standard check (b) heterosis and ranged from -29.71 for hybrid $\left(\mathrm{P}_{1} \times \mathrm{P}_{3}\right)$ to 127.09 for hybrid $\left(\mathrm{P}_{3} \times \mathrm{P}_{4}\right)$ for no. of fruit per plant.

Table 7: Percentage of heterosis in the $F_{1}$ generations over both mid and better parents for number of fruits and yield per plant characters of 15 eggplant $F_{1}$ hybrids.

\begin{tabular}{|c|c|c|c|c|}
\hline \multirow{2}{*}{ genotypes } & \multicolumn{2}{|c|}{ no. of fruit /plant } & \multicolumn{2}{|c|}{ Yield/plant } \\
\hline & M.p & B.p & M.p & B.p \\
\hline $\mathbf{P}_{1} \times_{\mathrm{P} 2}$ & 110.67" & 97.50 & 56.36 & 45.08 \\
\hline$\overline{\mathbf{P}_{1} \times \mathbf{P}_{3}}$ & -18.75 & $-25.71^{m+4}$ & 61.08 & 39.94 \\
\hline$\overline{\mathbf{P}_{1} \times \mathbf{P}_{4}}$ & $47.21^{m+n}$ & -10.49 & $57.57^{n+m}$ & $8.62^{2+2 t}$ \\
\hline$\overline{\mathbf{P}_{1} \times \mathbf{P}_{5}}$ & 71.43 & $57.14^{m+n}$ & 83.24 & $99.77^{\prime \prime}$ \\
\hline$\overline{\mathbf{P}_{1} \times \mathbf{P}_{6}}$ & -15.15 & -20.00 & $41.29^{* m}$ & 26.52 \\
\hline $\mathbf{P}_{2} \times \mathbf{P}_{3}$ & 24.64 & 7.50 & 99.60 & $62.77^{\prime \prime}$ \\
\hline $\mathbf{P}_{2} \times \mathbf{P}_{4}$ & 4.95 & -34.57 & 130.57 & 52.65 \\
\hline $\mathbf{P}_{2} \times \mathbf{P}_{5}$ & $19.51^{\prime \prime}$ & -69.75 & $39.97^{* / n}$ & -46.03 \\
\hline $\mathbf{P}_{2} \times \mathbf{P}_{6}$ & 85.92 & 65.00 & 205.11" & 155.80 \\
\hline $\mathbf{P}_{3} \times \mathbf{P}_{4}$ & -12.04 & -48.15 & $124.77^{\prime \prime}$ & 70.11 \\
\hline $\mathbf{P}_{3} \times \mathbf{P}_{5}$ & 85.92 & 57.14 & 106.81 & 93.42 \\
\hline $\mathbf{P}_{3} \times \mathbf{P}_{6}$ & 103.33 & $96.77^{\text {wn }}$ & 230.02 & 218.85 \\
\hline $\mathbf{P}_{4} \times \mathbf{P}_{5}$ & 20.59 & $-24.07^{* 1+}$ & 126.20 & $63.67^{\prime \prime}$ \\
\hline $\mathbf{P}_{4} \times \mathbf{P}_{6}$ & -68.91 & $-81.48^{* * 1 /}$ & 24.51*" & -7.94 \\
\hline $\mathbf{P}_{5} \times \mathbf{P}_{6}$ & -23.29 & -33.33 & $45.33^{\text {twm }}$ & 40.52 \\
\hline LCD 5\% & 9.71 & 11.22 & 1.14 & 1.32 \\
\hline LCD 1\% & 13.00 & 15.01 & 1.53 & 1.77 \\
\hline
\end{tabular}

* significant and ** highly significant at 0.05 and 0.01 levels of probability, respectively. 
Table 8: Heterosis (\%) values standard checks (La'ala a $)^{\mathrm{Z}}$ and (Black king $\left._{b}\right)^{z}$ for for number of fruits and yield per plant characters of 6 eggplant $F_{1}$ hybrids.

\begin{tabular}{|c|c|c|}
\hline Genotypes & No. of fruit /plant & Yield/plant \\
\hline $\mathbf{P}_{1} \times \mathbf{P}_{2}$ & $-30.70_{a}$ & $-55.43_{a}$ \\
\hline $\mathbf{P}_{1} \times \mathbf{P}_{4}$ & 27.19a & -11.89 a \\
\hline $\mathbf{P}_{1} \times \mathbf{P}_{5}$ & $-42.11_{a}$ & $-38.63_{a}$ \\
\hline $\mathbf{P}_{2} \times \mathbf{P}_{4}$ & $-7.02_{\mathrm{a}}$ & $23.82_{a}$ \\
\hline $\mathbf{P}_{2} \times \mathbf{P}_{5}$ & $-57.03_{a}$ & $-56.22_{a}$ \\
\hline $\mathbf{P}_{4} \times \mathbf{P}_{5}$ & 7.89 a & 32.76 \\
\hline $\mathbf{P}_{1} \times \mathbf{P}_{3}$ & $-29.71_{b}$ & $-43.04_{b}$ \\
\hline $\mathbf{P}_{1} \times \mathbf{P}_{6}$ & $-24.31_{b}$ & $-40.98_{b}$ \\
\hline $\mathbf{P}_{2} \times \mathbf{P}_{3}$ & $16.24_{b}$ & $-18.56_{b}$ \\
\hline $\mathbf{P}_{2} \times \mathbf{P}_{6}$ & $78.43_{b}$ & $19.33_{\mathrm{b}}$ \\
\hline $\mathbf{P}_{3} \times \mathbf{P}_{4}$ & $127.09_{b}$ & $65.72_{b}$ \\
\hline $\mathbf{P}_{3} \times \mathbf{P}_{5}$ & $78.43_{b}$ & $-3.22_{b}$ \\
\hline $\mathbf{P}_{3} \times \mathbf{P}_{6}$ & $64.91_{b}$ & $59.53_{\mathrm{b}}$ \\
\hline $\mathbf{P}_{4} \times \mathbf{P}_{6}$ & $-18.90_{b}$ & $-10.31_{b}$ \\
\hline $\mathbf{P}_{5} \times \mathbf{P}_{6}$ & $-24.31_{b}$ & $-34.45_{b}$ \\
\hline
\end{tabular}

$\mathrm{Z}$ a standard check Lal,la hybrid long fruit and b Black King hybrid round fruit

Data in Table (7) exhibited all hybrids highly significant positive values of heterosis over the mid-parent for total fruit per plant. The hybrid $\left(\mathrm{P}_{3} \times \mathrm{P}_{6}\right)$ had the highest value $(230.02 \%)$, while the hybrid $\left(\mathrm{P}_{4} \times\right.$ $\mathrm{P}_{6}$ ) had the lowest one $(24.51 \%)$. In the case of, heterosis over the better-parent, showed that most hybrids had highly significant positive values of heterosis over the better-parent, except two hybrids had highly significant negative values were cross $\left(\mathrm{P}_{2} \times \mathrm{P}_{5}\right)$ and $\left(\mathrm{P}_{4} \times \mathrm{P}_{6}\right)$ with $(-$ 46.03 and -7.94 , respectively), and the hybrid $\left(\mathrm{P}_{3} \times \mathrm{P}_{6}\right)$ had the highest value $(218.85 \%)$ for yield per plant. About standard check heterosis presented rustles in Table 8 Two out of the 6 evaluated $F_{1}$ hybrids increase positive over hybrids (La'ala) standard check (a) heterosis and ranged from $-56.22 \%$ for the cross $\left(\mathrm{P}_{2} \times \mathrm{P}_{5}\right)$ to $32.76 \%$ for the cross $\left(\mathrm{P}_{4}\right.$ $\times \mathrm{P}_{5}$ ) for yield per plant. However, standard check $(\mathrm{b})$ heterosis showed rustles 3 out of 9 evaluated $F_{1}$ hybrids highest positive over hybrids (Black king) standard check (b) heterosis and ranged from -43.04 for hybrid $\left(\mathrm{P}_{1} \times \mathrm{P}_{3}\right)$ to 65.72 for hybrid $\left(\mathrm{P}_{3} \times \mathrm{P}_{4}\right)$ for yield per plant. These results are in agreement with those reported by Naresh et al., (2013) who estimated significant positive heterosis, based on mid-parent, ranged from 21.04 to112.64\% in 36 crosses of eggplant and found that the maximum heterosis for fruit yield per plant was exhibited by the cross KS-8507 x KS-7512 (112.64\%) followed by KS-5623 x KS-7512 (110.39\%) and KS-8204-2 x KS-8822(92.47\%). 


\section{REFERENCES}

Agoreyo, B.O.; E. S. Obansa and E.O. Obanor (2012). Comparative nutritional and phytochemical analyses of two varieties of Solanum melongena. Science World Journal, 7(1): 5-8.

Ajjappalavara, P.S. (2006). Genetic studies and management of bacterialwilt in brinjal (Solanum melongena L.) $\mathrm{Ph}$. D. thesis, Uni. of Agric. Sci., Dharwad (India).

Al-Hubaity, A.I. (2013). Cobining ability and heterosis in eggplant (Solanum melongena L.).Mesopotamia J. of Agric., 41 (1): 1815316.

Gomez, A. K. and A. A. Gomez (1984). Statistical Procedures for Agricultural Research. $2^{\text {nd }}$ ed. John Wiley \& Sons Pub. pp. 139153.

Hamada, M. S.; A. F. Hamaiel; S. M. Farid and M. M. El-Kady (2016). Heterosis and combining ability for some traits of intersrecific and interspecificfic hybridization between Solanum melongena and Solanum macrocarpon. J. Agric. Res. Kafr ElSheikh Univ., 42(3): 34-45.

Joshi, A. and M. C.Thakur (2003). Exploitation of heterosis for yield and yield contributing traits in tomato (Lycopersicon esculentum Mill.). Progressive Horticulture., 35(1): 64-68.

Kumar, R.; J. P. Shahi and K. Srivastava (2013). Estimation of heterosis in field corn and sweet corn at marketable stage. The Bioscan., 8 (4):1165-1170.

Kumar, R. S.; T. Arumugam; C. R. Anandakumar and D. S. Rajavel (2012). Estimation of Heterosis and Specific Combining Ability forYield, Quality, Pest and Disease Incidence in Eggplant (Solanum melongena L.). Bulletin of Environment, Pharmacology and Life Science., 2(1): 03- 5.

Mahmoud, I. M. (2014). Heterosis in relation to combining ability variance sin eggplant (Solanum melongena L.) Hort. Jo. of Suez Canal Univ., Volume (2): 1-12.

Makani, A. Y.; A. L.Patel;M. M. Bhatt and P. C. Patel (2013). Heterosis for yield and its contributing attributes in Brinjal (Solanum melongena L.). The Bioscan., 8(4): 1369-1371.

Nagai, K. and M. Kada (1926). An experiment with some varietalcrosses of eggplants.Japanese J. Genetics. 4: 10-30.

Naresh, B.V.; A.K. Dubey; P.K. Tiwari and P. Avani (2013). Heterosis studies for yield components and Cercospora leaf spot 
resistance in brinjal (Solanum melongena L.). Progressive Rese., 8 (Special): 410-412.

Naresh, B.V.; A.K.Dubey; P.K. Tiwari and M.R. Dabbas (2014). Line $\mathrm{x}$ tester analysis for yield components and Cercosporaleaf spot resistance in brinjal (Solanum melongena L.). Electronic Jo. of Plant Breed., 5(2): 230-235

Nyadanu, D. and S.T. Lowor (2015). Promoting competitiveness of neglected and underutilized crop species: Comparative analysis of nutritional composition of indigenous and exotic leafy and fruit vegetables in Ghana. Genetic Resources and Crop Evolution, 62(1):131-140.

Patel, J.P.; S.Umesh; S.P.Kashyap; D.K.Singh; A. Goswami; S.K. Tiwari and M. Singh.2013. Combining ability for yield and other quantitative traits in eggplant (SolanummelongenaL.).Veg. Sci., 40(1): 61-64.

Potla, K. R.; S. S. Bornare; L. C. Prasad; R. Prasadand and A. H. Madakemohekar (2013). Study of heterosis and combining ability for yield and yield contributing traits in barley (Hordeum vulgare L.).The Bioscan., 8(4): 1393-1401.

Roychowdhury, R.; S. Roy and T. Jagatpati (2011). Estimation of heritable components of variation and character selection in eggplant (Solanum melongena L.) for mutation breeding programme. Continental J. Biological Sci., 4 (2): $31-36$.

Sarker, R.H.; S. Yesmin and M. I. Hoque (2006). Multiple shoot formation in eggplant (Solanum melongena L.). Plant Tissue Cult Biotech., 16:53-61.

Sao, A. and N. Mehta (2010). Heterosis in relation to combining ability for yield and quality attributes in Brinjal (Solanum melongena L.). Electronic J. Plant Breed., 1(4): 783-788.

Sinha, S. K. and R. Khanna (1975). Physiological, biochemical and genetic basis of heterosis. Advances in Agronomy, 27(1):123174.

Singh, A.K. ; R.S. Pan and P. Bhavana (2013). Heterosis and combining ability analysis in Bittergourd (momordic acharantia L.). The Bioscan. 8(4): 1533-1536.

Thakur, A.K.; U.K. Kholi and A. Joshi (2004). Evaluation of diallelprogeny and heterosis for yield and yield components in tomato (Lycopersicon esculantum Mill.). Haryana J. Horticultural Science, 33(1\&2): 106-108.

Waller, R. A. and D. B. Duncan (1969). A bays rule for the symmetric multiple comparison problems. Amer. Stat. Assoc. J., 64: 14851503. 


\section{تقدير قوة الهجين لبعض هجن الباذنجان

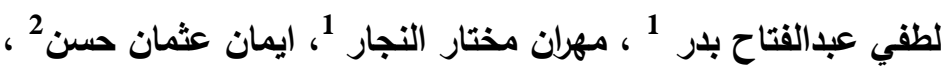 \\ عبير عبدالقادر سليمان 3 و محمود سعد عامر 3}

(1) قسم البساتين - كلية الزراعة - جامعة بنها - (2) قسم وقاية النبات كلية الزراعة - جامعة بنها و و(3) قسم

بحوث تريبة الخضر والنباتات الطيبة والعطرية - معهد بحوث البساتين - مركز البحوث الزراعية.

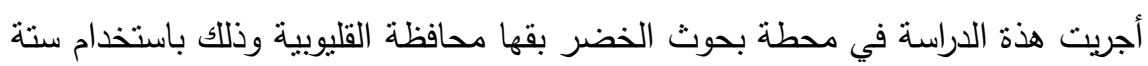

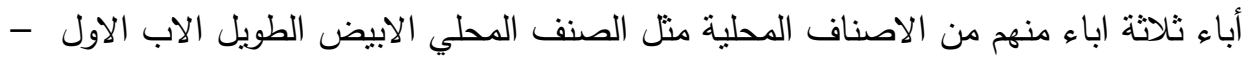

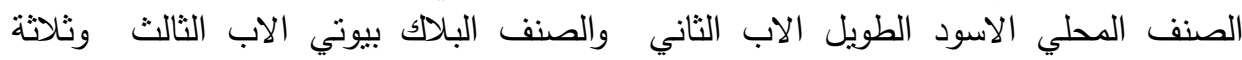

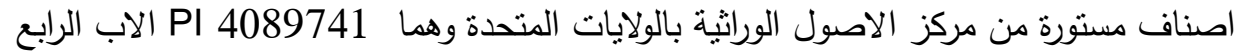

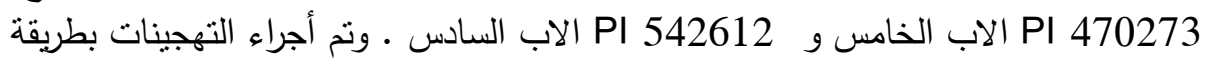

الهجن الدا في اتجاه واحد بدون استخدام الخجن العكسية. ونم تقدير قوة الهجين بالنسبة لمتوسط

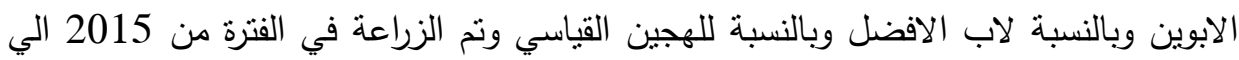

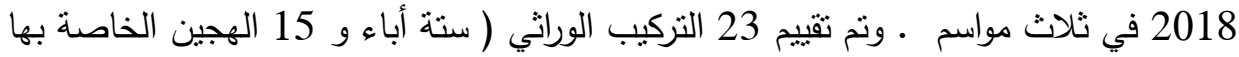

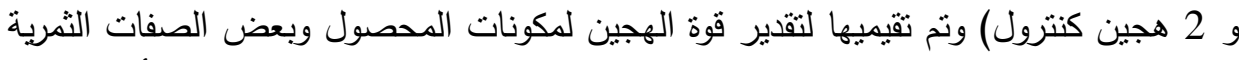

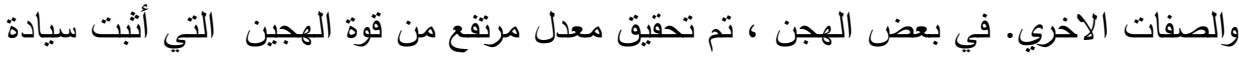
تامة لمعظم الصفات وكان الهجين (P3*P6) اعطي اعلي قوة هجين بالنسبة لمتوسط الابوين

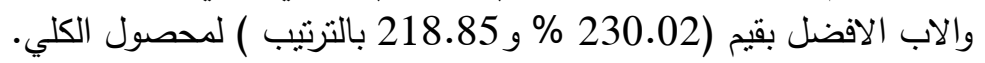

